\title{
Gürcan Çetin
}

Ph.D. (Electronic and Computer Education),

Assistant Professor of the Department of Information System Engineering

Muğla Sitkı Koçman University, Muğla, Turkey

gcetin@mu.edu.tr

\section{Osman Özkaraca}

Ph.D. (Electronic and Computer Education),

Assistant Professor of the Department of Information System Engineering

Muğla Sitkı Koçman University, Muğla, Turkey

osmanozkaraca@mu.edu.tr

\section{Murat Sakal}

Ph.D. (Business) Ongoing,

Instructor of the Department of Informatics (Distance Education Centre)

Muğla Sitkı Koçman University, Muğla, Turkey

murat@mu.edu.tr

\section{Ercüment Güvenç}

Master (Information Systems Engineering) Ongoing,

Instructor of the Department of Informatics (Distance Education Centre)

Muğla Sitkı Koçman University, Muğla, Turkey

eguvenc@mu.edu.tr

\section{A USABILITY ASSESSMENT OF AN EPUB 3.0 BASED EBOOK DEVELOPED FOR ALGORITHMS AND PROGRAMMING COURSE}

\begin{abstract}
The digital self-learning among students is becoming increasingly popular with the widespread use of mobile devices. In this context, many academic institutions generate digital learning sources for their learners. EBooks offer new opportunities in the matter of the visualization of educational materials, access them from any place at any time. It is inevitable to use interactive eBooks in engineering education as well. This paper presents an eBook for students studying in Information System Engineering. It has been aimed to enhance algorithmic skills of students. Moreover, in this article, we have evaluated the usability of this eBook. The results of research show how the students assessed the interface quality, information quality and overall satisfaction of our eBook. The research was conducted by using a questionnaire method.
\end{abstract}

Keywords: EBook; EPUB3.0; eBook usability; interactive of algorithms and programming.

\section{INTRODUCTION}

The popularity of the "Digital self-learning technology" [1] has started to increase in recent years. In parallel with the rising of the knowledge as a result of the scientific and technological innovations, the number of Internet and mobile device users are increasing to access this information too. It has become clear that reading habits of people are shifting from printed media to digital media [2]. One of the most important types of digital media is eBooks. When eBooks were first published, they consisted of only texts, but new generation eBooks have rich content such as images, graphics, sounds, videos, animations, simulations and interactive widgets [3].

There are many eBook standards such as PDF (Portable Document Format), iBook, EPUB (Electronic PUBlication), Kindle, HTML (Hyper Text Markup Language), Mobipocket RTF (Rich Text Format), Microsoft Word and so on. However, so many formats that are incompatible with each other cause adaptation problems for mobile devices and eBook readers [4]. Thus, in the design phase of the eBook, one of the appropriate formats like PDF, iBook or EPUB should be preferable in order to reach a wide audience. 
PDF is one of the most used formats to create an eBook, since it can work efficiently on many computers without disturbing its original quality. However, attempting to maintain original quality can cause display problems for mobile devices because of the font sizes or failure to comply with screen. On the other hand, the iBook was introduced by Apple as an eBook standard for iPhone, iPod, iPad and Mac users. It has a rich content that allows to add swipe-friendly photo galleries, animations that burst off the page, scrolling sidebars to linger over, Pop-Over widgets for an element and 3D objects [5]. As an international eBook format, EPUB was presented by IDPF (International Digital Publishing Forum) based on explicit specifications written in XML and XHTML. The EPUB standard defines a means of encoding, packaging and representing which are arranged and semantically enriched Web content containing XHTML, CSS, SVG, images and other resources. One of the important features is its portability for many different devices and platforms such as iPhone, iPad, iPod, Android, Stanza, MobiPocket, Adobe Digital Editions, Sony Reader, Nook, FBReader and so on [4].The final recommended specification of EPUB (EPUB 3.0) was announced by IDPF in 2011. It supports HTML5 and CSS3 standards to design interactive elements in an eBook [6, 7].

The problem statement. The improvement of eBook standards and the widespread acceptance of eBook readers are forcing about how some functions of the books should be used in education [8].Furthermore, eBooks create new opportunities for learners in terms of the visualization of educational materials and accessing them whenever they want. At this point, it is inevitable to use interactive eBooks resources in engineering education as well. One of the biggest challenges in teaching computer-related topics, especially in the Computer Engineering education, is the inability to show directly how the computer identifies the data, how it uses memory, and how it performs operations. The most important feature of eBooks is that it allows the use of animations, simulations and other visual materials to describe the content in addition to its many features such as its portability, ease of navigation, linking to other materials, easy searching and taking notes. It has been seen that the interest of the students is lost quickly in the lessons which are carried out without using interactive content, and some theories are not understood precisely. The simulations attract the attention of the students primarily because they improve the students' ability to visualize in their minds [9].

Analysis of recent studies and publications. Different studies have been realized to evaluate the use of eBooks in engineering education. In the study [10], an eBook was developed for teaching Pascal programming language and used by students during the course. The students said that they felt much more comfortable because they did not have the supervisors while working with the eBook. Moreover, it has been detected that this situation increased students' demand on Pascal learning. In the research literature, studies [11-13] have also shown that eBook usage is preferable when interactive content is used. Moreover, the engineering students perceive the eBook as a useful educational material [14]. In 2016, a survey was conducted [15] to explore the awareness, usage and attitudes of undergraduate and graduate students towards eBooks by in China. The findings of the study showed that undergraduate students generally use eBooks for the purpose of leisure, while graduate students tend to use eBooks for academic purposes. Another research [16], which was carried out in 2014, focuses on the awareness, perceptions and the use of eBooks by the academic staff rather than students. The results of the study show that academic staff are open-minded about eBooks and see them as a source. The other researchers [17] have also reported that academic staff was much more excited about using eBooks at the beginning than were the students. When eBooks are planned with suitable media components, and technical problems are avoided, they are seen as a candidate for today's learning-teaching process [18].

The article's goal is to introduce an eBook designed to improve the algorithmic skills of computer engineering students, and is evaluate of the usability of this eBook which is 
provided as a resource for the students in the department of Information System Engineering in Muğla Sitkı Koçman University. The CSUQ (Computer System Usability Questionnaire) developed at IBM [19] was used in this study, and information quality, interface quality and students' overall satisfaction about eBook were evaluated.

\section{RESEARCH METHODS}

\subsection{An Interactive eBook for Algorithms and Programming Course}

Algorithm and Programming course includes flow diagrams and programming logic of the algorithms. It is important to teach the basic principles of computer programming in the field of Computer Science. The goal of the course is to teach learners how to design an algorithm, and how to analyze a problem, as well as to teach them basic knowledge of structured programming. Several problems are addressed in this course and their algorithms and flow diagrams are presented to solve these problems in practice. Moreover, it is also expected that learners will be able to use a programming language effectively at the end of this course. In the phase of preparation of the contents, we surveyed the literature relevant to Algorithm and Programming course, and searched the interactive applications on web sources. We have also chosen the $\mathrm{C}$ programming languages as the initial language according to our curriculum. We consequently organized our eBook as 9 sections; Introduction to computer programming, Algorithms and Flow Diagrams, C Programming Language, Data types and Operators, Standard C Library, Control Structures and Logical Operators, Loops, Functions and Arrays. We have developed this interactive eBook as an additional source for our learners taking this course in the department of Information System Engineering. Figure1 shows a screenshot of the designed page of the eBook about a simple $\mathrm{C}$ programming structure and preprocessor directives on a tablet computer.

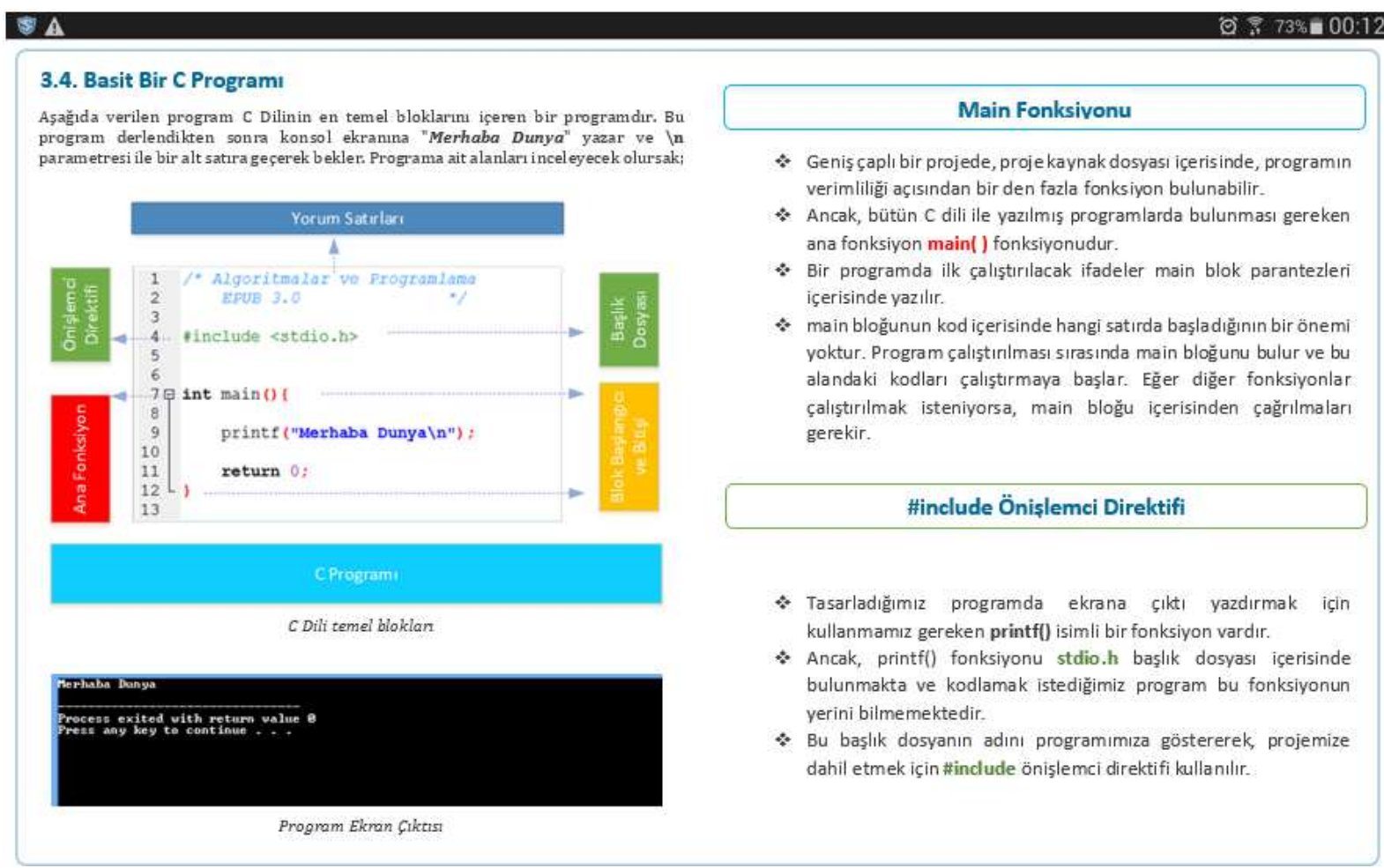

Figure1. A designed page on eBook Reader 
It has been aimed to a better explanation of the Algorithms and Programming course by using graphical materials, animations and simulations. We coded these elements with HTML5 and JavaScript based on jQuery library. So, the developed eBook can be supported by different media and can work with different formats. In the design level of the eBook, we have utilized hyperlinked texts to combine content and we also preferred font faces and font sizes to ensure selectable readability. Figure 2 shows another screenshot of a designed page about algorithms on an eBook reader.

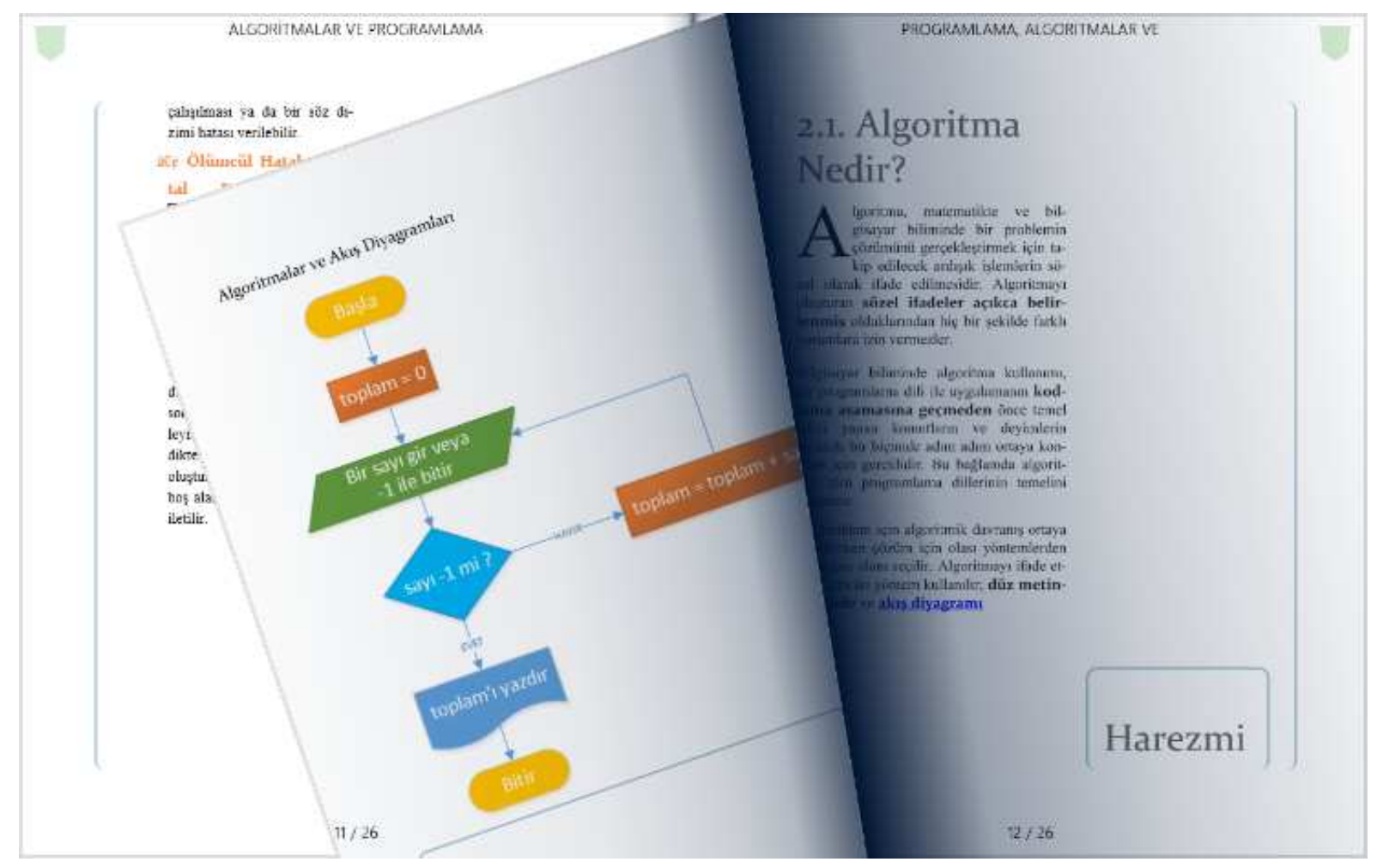

Figure 2. A designed page on eBook Reader

The challenges in expressing and visualizing the theoretical content that is desired to be taught to the learners can be eliminated by means of animations and simulations. The use of interactive elements allows the learners to develop the skills of putting the theoretical knowledge into practice, as well as to enhance learning efficiency. Therefore, great importance has been attached to the availability of animations and simulations in our eBook. These interactive components provide an obvious demonstration of the flow diagrams and algorithm design. Moreover, they simulate the abstract processing steps in the computer memory and CPU during programming. A sample animation seen in Figure 3 shows how the data in a multidimensional array is represented in rows and columns and how it is stored in sequential order according to the size of the data in the computer memory. 

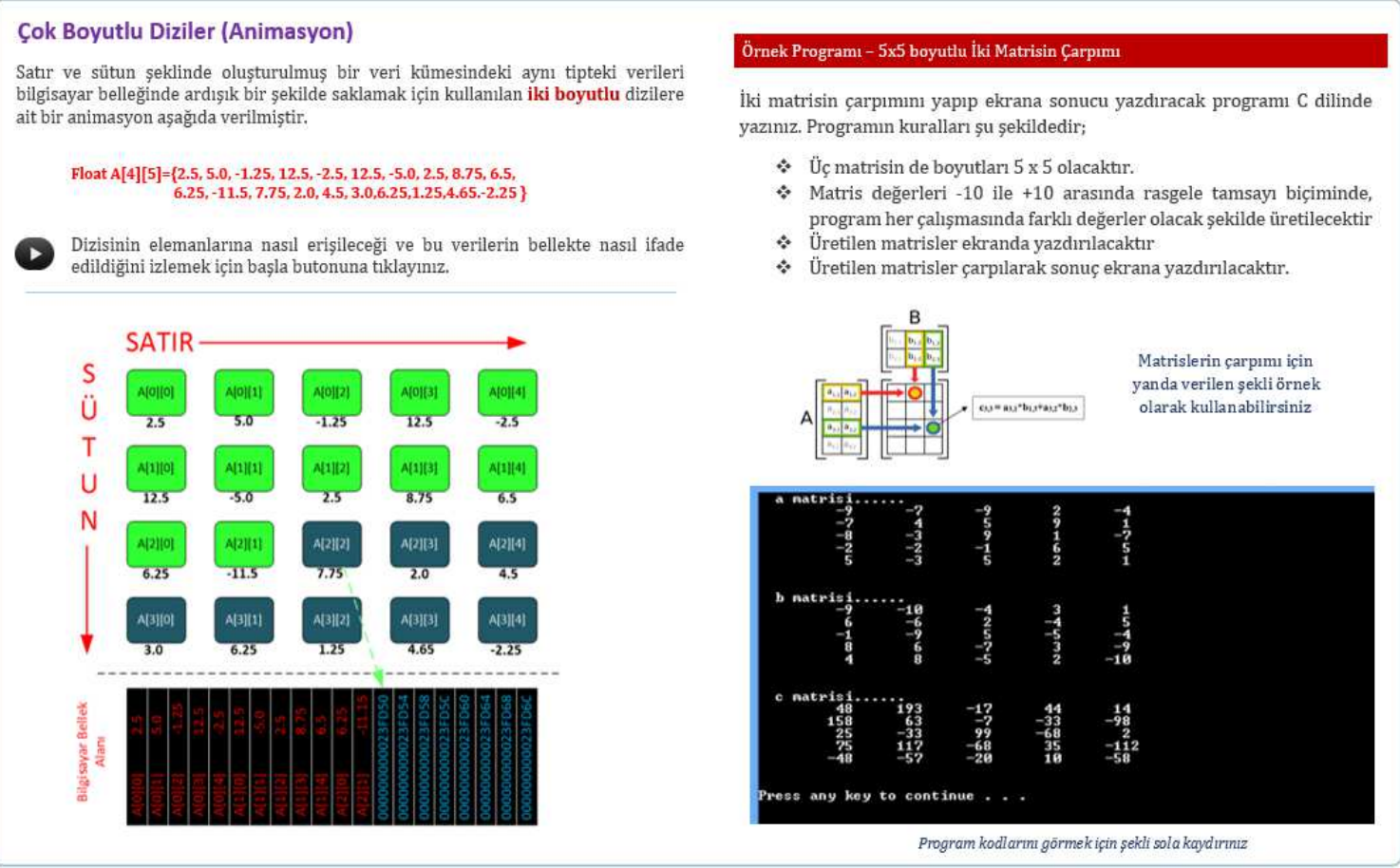

Figure 3. A sample of animation about multidimensional arrays

In addition to animations and simulations, we embedded content effects in the pages of the eBook. These effects are horizontal sliding image panels, horizontal or vertical tutorial panels, pop-up texts and reveal panels. The main aim is to ensure that the learners do not lose their interest during the course presentation. A sliding image panel effect prepared to see the output of the $\mathrm{C}$ code can be seen in Figure 4.

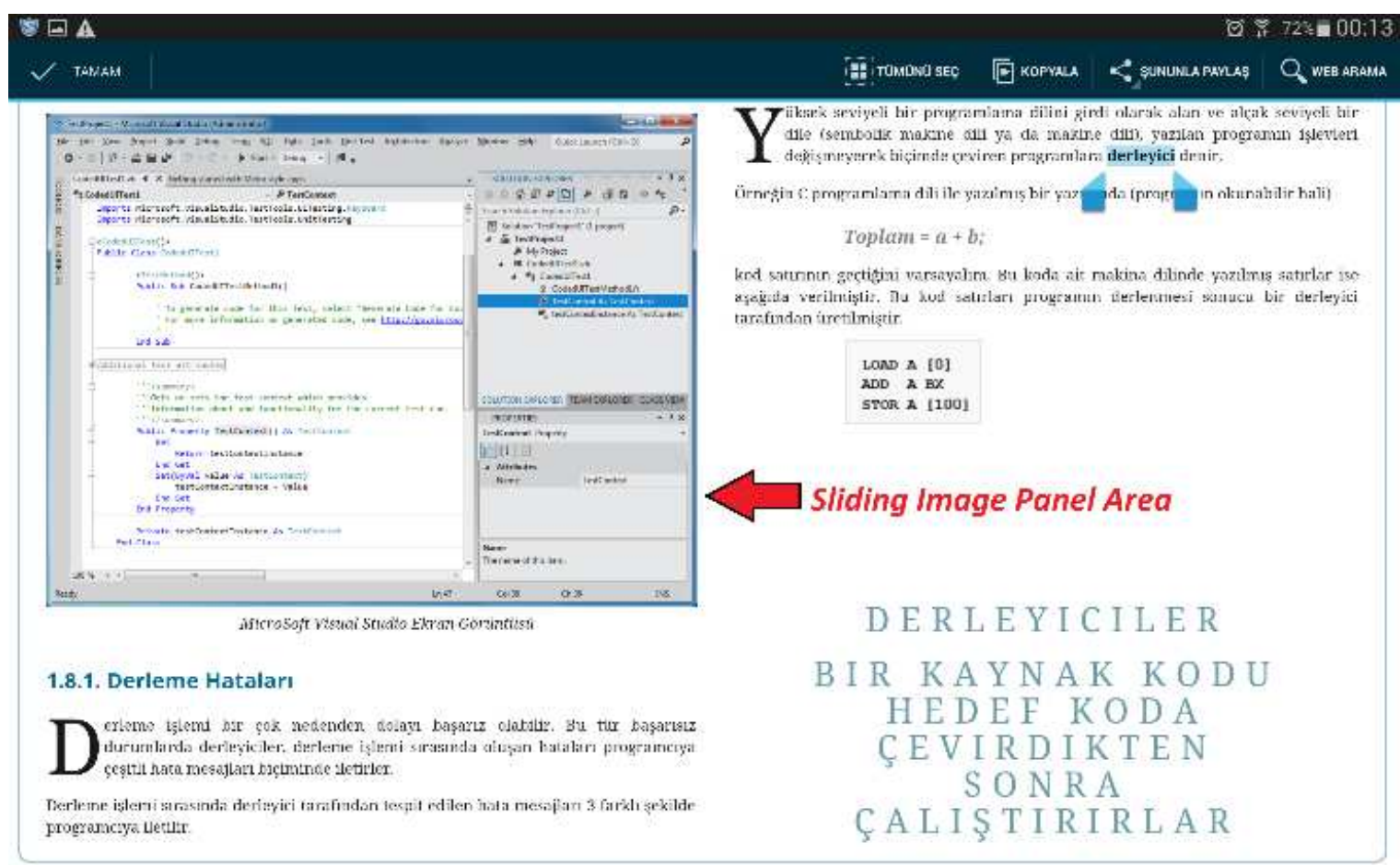

Figure 4. Sliding image panel effect 
Each section of the eBook contains interactive chapter break tests such as multiplechoice, multiple-response, true-false, text-match, association, sequence, and sort word exercises. Figure5 (a) shows a sample of the true-false question type, and another example of multiple-choice questions is shown in Figure5 (b). The actual aim is that the learners test themselves about what they learned after the completion of a unit. Hence, successful learning of the phenomena and effective implementation of critical thinking skills about programming codes are ensured. Nevertheless, we did not intend to assess the total score of a student in these tests. After the options of the question are checked, the right answers are showed only.

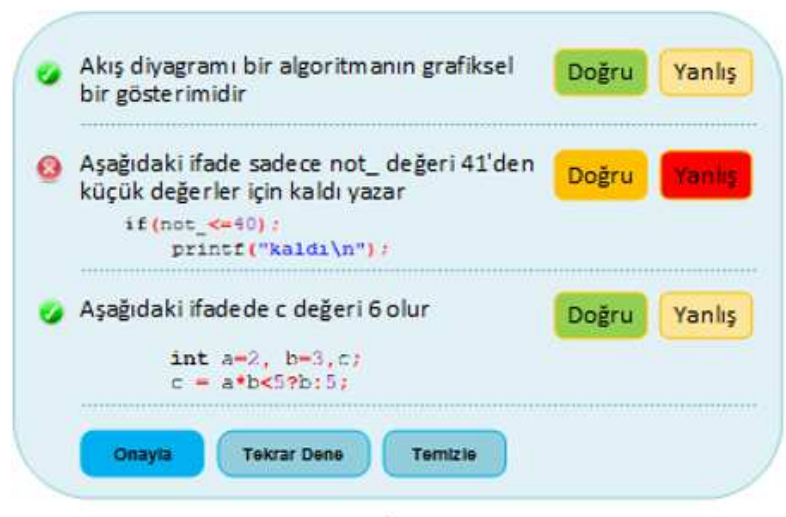

a)

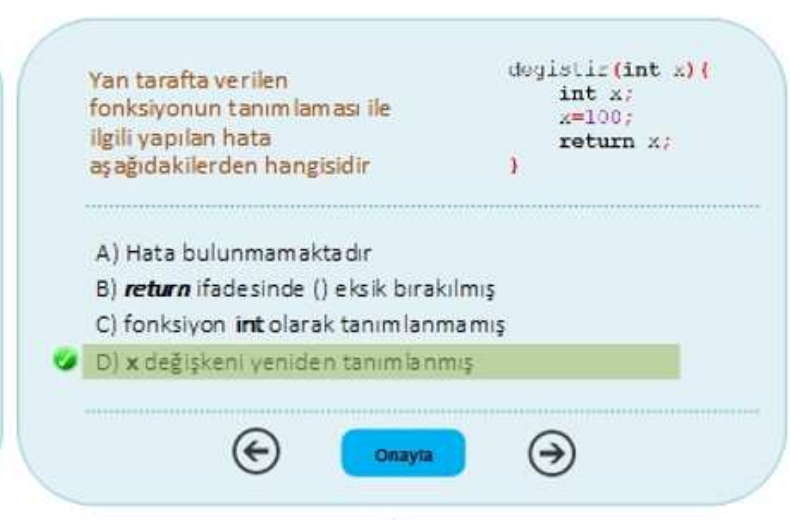

b)

Figure 5. Chapter break tests a) true-false questions b) multi-choice questions

\subsection{Survey}

The convenience sampling consisted of the 1st grade students of the Muğla Sitk1 Koçman University Information Systems Engineering Department. The survey on students was conducted from October to December 2016.

The Computer System Usability Questionnaire - Short Version (T-CSUQ-SV) used in the study was adapted for studies conducted in Turkish [19].The CSUQ, developed at IBM for internal use, is a widely used questionnaire for the usability satisfaction of a computer system [20]. The CSUQ, first published in 1995 and maintaining its update in the literature, consists of 19 items from four categories; system usefulness (1-6. items), information quality (7-9. items), interface quality (10-12. items) and overall satisfaction (13. items). The students were asked to mark their answers on a seven-point Likert scale from 1(strongly agree) to 7 (strongly disagree). In the study, the students filled in the CSUQ after the end of the first semester. Moreover, in our questionnaire, we added (1) a demographic information on gender, (2) an item asking about how long they use the computer effectively, and (3)an item asking about how they got knowledge.

A total of 53 completed questionnaires were received. The total number of students in a lesson was approximately 60. 18 (34\%) of them are female, and $35(66 \%)$ of them are male. The age range of the students varies between 17 and 34. According to the response given by participants in the question "How long do you use the computer systems effectively?", 67.6\% $(n=36)$ of the participants used more than 5 years, $13.2 \%(n=7)$ of them used between $4-5$ years, 9.7\% $(n=5)$ of them used between $2-3$ years and $7.5 \%(n=4)$ of them used between $0-1$ years. The students were asked "how they got knowledge about the course". 69.8\% $(n=37)$ of the students read from the computer, tablet or telephone, $13.2 \%(\mathrm{n}=7)$ of them only reached the knowledge with printed sources, and $15.1 \%(n=8)$ of them reached in both ways. 


\section{THE RESULTS AND DISCUSSION}

\subsection{The Assessment of the Usefulness of the eBook}

The percentages values and frequencies of the usefulness towards usability of the eBook designed as the course materials are presented in Table 1.

Table 1

Frequencies \& Percentages related to the usefulness of the eBook

\begin{tabular}{|c|c|c|c|c|c|c|c|c|c|c|c|c|c|c|}
\hline \multirow{2}{*}{\begin{tabular}{|l|}
\multicolumn{1}{|c|}{ Questions } \\
$\begin{array}{l}\text { Q1: Overall, I am } \\
\text { satisfied with how easy } \\
\text { it is to use this eBook }\end{array}$ \\
\end{tabular}} & \multicolumn{2}{|c|}{$\begin{array}{c}1 \\
\text { Strongly } \\
\text { Agreed }\end{array}$} & \multicolumn{2}{|c|}{$\begin{array}{c}2 \\
\text { Slightly } \\
\text { Agreed }\end{array}$} & \multicolumn{2}{|c|}{$\begin{array}{c}3 \\
\text { Agreed }\end{array}$} & \multicolumn{2}{|c|}{$\begin{array}{c}4 \\
\text { Neutral }\end{array}$} & \multicolumn{2}{|c|}{$\begin{array}{c}5 \\
\text { Disagreed }\end{array}$} & \multicolumn{2}{|c|}{$\begin{array}{c}6 \\
\text { Slightly } \\
\text { Disagreed }\end{array}$} & \multicolumn{2}{|c|}{$\begin{array}{c}7 \\
\text { Strongly } \\
\text { Disagreed }\end{array}$} \\
\hline & 17 & $32 \%$ & 20 & $38 \%$ & 12 & $23 \%$ & 1 & $2 \%$ & 2 & $4 \%$ & 0 & $0 \%$ & 0 & $0 \%$ \\
\hline $\begin{array}{l}\text { Q2: It was simple to use } \\
\text { this eBook }\end{array}$ & 24 & $45 \%$ & 15 & $28 \%$ & 10 & $19 \%$ & 2 & $4 \%$ & 2 & $4 \%$ & 0 & $0 \%$ & 0 & $0 \%$ \\
\hline $\begin{array}{l}\text { Q3: I was able to } \\
\text { complete the tasks and } \\
\text { scenarios quickly using } \\
\text { this eBook }\end{array}$ & 15 & $28 \%$ & 19 & $36 \%$ & 13 & $25 \%$ & 4 & $8 \%$ & 1 & $2 \%$ & 1 & $2 \%$ & 0 & $0 \%$ \\
\hline $\begin{array}{l}\text { Q4: I felt comfortable } \\
\text { using this eBook }\end{array}$ & 21 & $40 \%$ & 21 & $40 \%$ & 7 & $13 \%$ & 2 & $4 \%$ & 1 & $2 \%$ & 1 & $2 \%$ & 0 & $0 \%$ \\
\hline $\begin{array}{l}\text { Q5: It was easy to learn } \\
\text { to use this eBook }\end{array}$ & 23 & $43 \%$ & 21 & $40 \%$ & 5 & $9 \%$ & 3 & $6 \%$ & 0 & $0 \%$ & 1 & $2 \%$ & 0 & $0 \%$ \\
\hline $\begin{array}{l}\text { Q6: I believe I could } \\
\text { become productive } \\
\text { quickly using this eBook }\end{array}$ & 10 & $19 \%$ & 15 & $28 \%$ & 16 & $30 \%$ & 7 & $13 \%$ & 3 & $6 \%$ & 2 & $4 \%$ & 0 & $0 \%$ \\
\hline
\end{tabular}

As seen in Table 1, the opinions of the students on the usability of the eBook can be interpreted as follows. $45 \%$ of the students who participated in the study stated that the usage of eBook was very simple. In addition, $43 \%$ of the students stated that the usability of eBook was easy, $32 \%$ of them were satisfied with the ease of use of eBook in general and $40 \%$ of them could use eBook easily. Although this is the general view of the students regarding the usability of the eBook, the answers to Q3 (28\%) and Q6 (19\%) were more negative views than the other answers. This is largely due to the fact that students need more time to adopt and use their knowledge especially in such courses. The result suggests that importance should be attached to the use of real life applications where students can apply more of the information they learn in the eBook.

\subsection{The Assessment of the Information Quality of the eBook}

The percentages values and frequencies of the information quality related to usability of the eBook designed as the course materials are presented in Table 2.

Table 2

Frequencies \& Percentages related to the information quality of the eBook

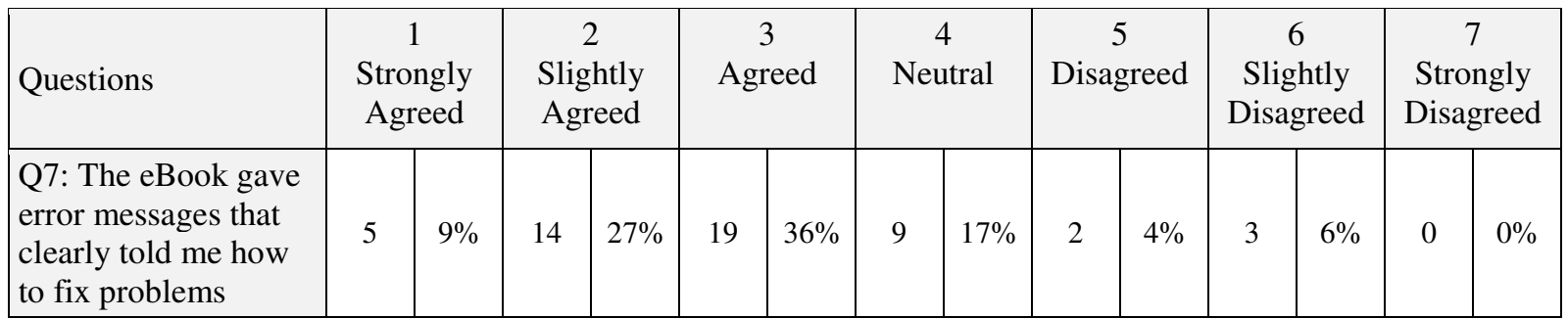




\begin{tabular}{|l|c|c|c|c|c|c|c|c|c|c|c|c|c|c|}
\hline $\begin{array}{l}\text { Q8: The information } \\
\text { (such as online help, } \\
\text { on-screen messages } \\
\text { and other } \\
\text { documentation) } \\
\text { provided with this } \\
\text { eBook was clear }\end{array}$ & 15 & $28 \%$ & 18 & $34 \%$ & 10 & $19 \%$ & 4 & $8 \%$ & 5 & $9 \%$ & 1 & $2 \%$ & 0 & $0 \%$ \\
\hline $\begin{array}{l}\text { Q9: It was easy to } \\
\text { find the information I } \\
\text { needed }\end{array}$ & 22 & $42 \%$ & 13 & $25 \%$ & 12 & $23 \%$ & 3 & $6 \%$ & 3 & $6 \%$ & 0 & $0 \%$ & 0 & $0 \%$ \\
\hline
\end{tabular}

According to Table 2, after we analyzed the questionnaires about information quality of the eBook, we evaluated the opinions of students participating in the study as follows; $42 \%$ of the students stated that the information given by the eBook is easily understood. $28 \%$ of the students reported that the information provided by the eBook was clear. These results give strong support to the information quality of the eBook. However, $9 \%$ of the participants only agreed that they definitely participated in the Q7. This is mainly due to the fact that the problems are mostly caused by eBook readers rather than eBooks. The error messages given to the problems are also limited to the messages that the eBook readers give. This point is also one of the factors affecting student satisfaction. EBook readers used by the students influence them also.

\subsection{The Assessment of the Interface Quality of the eBook}

The percentages values and frequencies of the interface quality related to usability of the eBook designed as the course materials are presented in Table 3.

Table 3

Frequencies \& Percentages related to the interface quality of the eBook

\begin{tabular}{|c|c|c|c|c|c|c|c|c|c|c|c|c|c|c|}
\hline \multirow{2}{*}{$\begin{array}{l}\text { Questions } \\
\text { Q10: The interface } \\
\text { of this eBook was } \\
\text { pleasant }\end{array}$} & \multicolumn{2}{|c|}{$\begin{array}{c}1 \\
\text { Strongly } \\
\text { Agreed }\end{array}$} & \multicolumn{2}{|c|}{$\begin{array}{c}\text { 2 } \\
\text { Slightly } \\
\text { Agreed }\end{array}$} & \multicolumn{2}{|c|}{$\begin{array}{c}3 \\
\text { Agreed }\end{array}$} & \multicolumn{2}{|c|}{$\begin{array}{c}4 \\
\text { Neutral }\end{array}$} & \multicolumn{2}{|c|}{$\begin{array}{c}5 \\
\text { Disagreed }\end{array}$} & \multicolumn{2}{|c|}{$\begin{array}{c}6 \\
\text { Slightly } \\
\text { Disagreed }\end{array}$} & \multicolumn{2}{|c|}{$\begin{array}{c}7 \\
\text { Strongly } \\
\text { Disagreed }\end{array}$} \\
\hline & 20 & $38 \%$ & 12 & $23 \%$ & 13 & $25 \%$ & 3 & $6 \%$ & 4 & $8 \%$ & 1 & $2 \%$ & 0 & $0 \%$ \\
\hline $\begin{array}{l}\text { Q11: I liked using } \\
\text { the interface of this } \\
\text { eBook }\end{array}$ & 17 & $32 \%$ & 17 & $32 \%$ & 8 & $15 \%$ & 8 & $15 \%$ & 2 & $4 \%$ & 1 & $2 \%$ & 0 & $0 \%$ \\
\hline $\begin{array}{l}\text { Q12: This eBook } \\
\text { has all functions } \\
\text { and capabilities I } \\
\text { expect it to have }\end{array}$ & 7 & $13 \%$ & 18 & $34 \%$ & 15 & $28 \%$ & 8 & $15 \%$ & 4 & $8 \%$ & 0 & $0 \%$ & 0 & $0 \%$ \\
\hline
\end{tabular}

According to Table 3, after we analyzed the questionnaires about interface quality of the eBook, we evaluated the opinions of students as follows; $38 \%$ of participants expressed that they liked the interface of the eBook. The number of students who liked to use the eBook interface was $17(32 \%) .13 \%$ of the respondents indicated that the eBook had all the functions and capabilities expected from it, and this was sufficient for the students.

\subsection{Overall Satisfaction of Students}

The answers given by the students to the item 13 of the questionnaire about the overall satisfaction of the eBook are given in Table 4. 
Table 4

Frequencies \& Percentages related to the overall satisfaction of the eBook

\begin{tabular}{|c|c|c|c|c|c|c|c|c|c|c|c|c|c|c|}
\hline \multirow{2}{*}{\begin{tabular}{|l} 
Questions \\
Q13: Overall, I \\
am satisfied with \\
\end{tabular}} & \multicolumn{2}{|c|}{$\begin{array}{c}1 \\
\text { Strongly } \\
\text { Agreed }\end{array}$} & \multicolumn{2}{|c|}{$\begin{array}{c}2 \\
\text { Slightly } \\
\text { Agreed }\end{array}$} & \multicolumn{2}{|c|}{$\begin{array}{c}3 \\
\text { Agreed }\end{array}$} & \multicolumn{2}{|c|}{$\begin{array}{c}4 \\
\text { Neutral }\end{array}$} & \multicolumn{2}{|c|}{$\begin{array}{c}5 \\
\text { Disagreed }\end{array}$} & \multicolumn{2}{|c|}{$\begin{array}{c}6 \\
\text { Slightly } \\
\text { Disagreed }\end{array}$} & \multicolumn{2}{|c|}{$\begin{array}{c}7 \\
\text { Strongly } \\
\text { Disagreed }\end{array}$} \\
\hline & 17 & $32 \%$ & 22 & $41 \%$ & 7 & $13 \%$ & 4 & $8 \%$ & 2 & $4 \%$ & 0 & $0 \%$ & & $0 \%$ \\
\hline
\end{tabular}

According to the opinions of the students participating in the study; while $32 \%$ of the students stated that the eBook was very satisfactory, $41 \%$ of them partially participated in this item.

\section{CONCLUSIONS AND PROSPECTS FOR FURTHER RESEARCH}

EBooks create new opportunities for students to visualize educational resources and provide access from anywhere at any time. It is inevitable to use interactive eBook resources in engineering education. One of the biggest challenges in teaching computer examples, especially in areas such as Computer Engineering education, comes from not being able to show directly how the computer identifies the data, how it uses memory, and how it does operations. For this purpose, we have developed an eBook with interactive elements, and its usability was evaluated by the students studying in Information System Engineering department. This section briefly summarizes the results of the research contained in the body. The students participating in this study expressed that:

- The usage of eBook is very simple (45\%) and the usage of eBook is easy (43\%).

- The information given by the eBook is easily understood (42\%), and the information provided by the eBook was clear $(28 \%)$.

- The interface of the eBook is very good (38\%), and the interface of the eBook is $\operatorname{good}(32 \%)$.

- The eBook was very satisfactory (32\%), and $41 \%$ of the students partially participated in this item.

After we analyzed the questionnaires, we found that the usability quality of the eBook was generally high. And, the students gave higher scores for user satisfaction. On the other hand, the answers to the question "I believe I could become productive quickly using this eBook" (19\%) were more negative views than the others. This is mainly due to the fact that students need more time to adopt and use their knowledge. Moreover, the usage of different eBook readers is one of the factors affecting student satisfaction.

\section{ACKNOWLEDGEMENT}

This work was supported by Muğla Sitkı Koçman University Scientific Research Projects with $15 / 106$ project code. 


\section{REFERENCES}

1. Çetin, G., Özkaraca, O., Güvenç, E., and Sakal, M. 2016. The Development of An eBook with Dynamic Content For the Introduction of Algorithms and Programming. Mugla Journal of Science and Technology, vol. 2, no. 2, pp. 199-203.

2. Yawei, H., Xueyao, L. 2012. An Analysis on the Dynamic Design of E-books of Digital Information Media in Present China. in 3rd IC on System Science, Engineering Design and Manufacturing Informatization.

3. Daş, A., Yıldırım, G., Bölen, M. C. and Çeliker, O. 2013. Etkileşimli E-Kitapların Tasarım Aşamalarının İncelenmesi ve Tasarım Farklılıklarının Belirlenmesi. in Akademik Bilişim.

4. Bidarra, J., Natalio, C., and Figueiredo, M. 2014. Designing eBook Interaction for Mobile and Contextual Learning. in IC on Interactive Mobile Communication Technologies and Learning (IMCL).

5. iBooks Author - Apple [Online]. Available from: http://www.apple.com/ibooks-author/

6. Okuda,S., Emi, K. and Kawachi, Y. 2012. Buillding of an Education System with Electronic Textbooks of the ePub Format and with Smartphones. in the 1st IEEE Global Conference on Consumer Electronics.

7. Shang, Z., Shi, C.2013. The Sudy of Personalized and Customized E-textbook Bases on EPUB3.0. in IC on Mechatronic Sciences, Electric Engineering and Computer.

8. Smith, M., Kukulska-Hulme, A. 2012. Building Mobile Learning Capacity in Higher Education: Ebooks and iPads. in 11th World Conference on Mobile and Contextual Learning.

9. Oruc, A., Y., Gunduzhan, E. 2003. A visual instruction set architecture and simulation tool for computer engineering education. in 33rd Annual Frontiers in Education.

10. Aedo, I., Diaz, P., Fernandez, C., Martin, G., M., and Berlanga, A., 2000. Assessing the utility of an interactive electronic book for learning the PASCAL programming language.IEEE Transactions on Education, vol. 43, no. 3, pp. 403-413.

11. Xiaoqing, G., Wu, B., and Xu, X. 2015. Design Development, and learning in e-Textbooks: What we learned and where we are going.Journal of Computers in Education, vol. 2, no. 1, pp. 25-41.

12. Restive, M. T., Chouzal, M. D. F., Almeida, F., G., Mendes, J., and Lopes, A., M. 2009. An innovative e-book on the measurement field. in EUNIS 2009.

13. Ismail, R., Zainab, A. 2007. Factors Related to E-books Use amongst IT Students. in International Conference on Libraries, Information and Society.

14. Jou, M., Tennyson, R., D., Wang, J., Huang, S., Y. 2016. A study on the usability of E-books and APP in engineering courses: A case study on mechanical drawing.Computers \& Education, Vol 92-93, pp 181-193.

15. Wang, S., Bai, X. 2016. University Students Awareness, Usage and Attitude Towards E-books: Experience from China.The Journal of Academic Librarianship, vol. 42, no. 3, pp. 247-258.

16. Mulholland, E., Bates, J. 2014. Use of Perceptions of E-books by Academic Staff in Further Education.The Journal of Academic Librarianship, vol. 40, pp. 492-499.

17. Gueval, J., Tarnow, K. and Kumm, S. 2015. Implementing e-books: Faculty and student experiences.Teaching and Learning in Nursing, vol. 10, no. 4, pp. 181-185.

18. Öngöz, S. 2011. Bir Öğrenme-Öğretme Aracı Olarak Elektronik Kitap. in 5th International Computer \& Instructional Technologies Symposium.

19. Erdinç, O., Lewis,J. R. 2013. Psychometric Evaluation of the T-CSUQ: The Turkish Version of the Computer System Usability Questionnaire.International Journal of Human-Computer Interaction, vol. 29, pp. 319-326.

20. Lewis, J., R. 1995. IBM Computer Usability Satisfaction Questionnaires: Psychometric Evaluation and Instructions for Use.International Journal of Human-Computer Interaction, vol. 7, pp. 57-78. 


\title{
ОЦННЮВАННЯ ЗРУЧНОСТІ ВИКОРИСТАННЯ ЕЛЕКТРОННОӤ КНИГИ НА ОСНОВІ ЕРUВ 3.0 ДЛЯ КУРСУ 3 АЛГОРИТМІВ І ПРОГРАМУВАННЯ
}

\section{Гурджан Четін}

Ph.D. (Електронна і Комп'ютерна освіта), доцент кафедри інформаційних систем інженерії Університет Muğla Sitkı Koçman, Мугла, Туреччина gcetin@mu.edu.tr

\section{Осман Озкараджа}

Ph.D. (Електронна і Комп'ютерна освіта), доцент кафедри інформаційних систем інженерії Університет Muğla Sitkı Koçman, Мугла, Туреччина osmanozkaraca@mu.edu.tr

\author{
Мурат Сакал \\ здобувач Ph.D.(Бізнес), \\ викладач кафедри інформатики (Центр дистанційної освіти) \\ Університет Muğla Sitkı Koçman, Мугла, Туреччина \\ murat@mu.edu.tr \\ Ерджумент Гювенч \\ здобувач ступеня магістра (Інформаційні системи інженеріi), \\ викладач кафедри інформатики (Центр дистанційної освіти) \\ Університет Muğla Sitkı Koçman, Мугла, Туреччина \\ eguvenc@mu.edu.tr
}

\begin{abstract}
Анотація. Цифрове самонавчання 3 використанням мобільних пристроїв стає все більш популярним серед студентів. У цьому контексті, багато наукових установ створюють для своїх учнів навчальні цифрові ресурси. Електронні книги (EBooks) відкривають нові можливості з точки зору візуалізації навчальних матеріалів, доступ до яких можливий 3 будь-якого місця в будь-який час. Використання інтерактивних електронних книг у галузі інженерної освіти стає неминучим. У цій роботі представлено електронну книгу для студентів, які навчаються на кафедрі Інформаційні системи інженерії. Ця книга сфокусована на підвищенні рівня алгоритмічних навичок студентів. Попри це, у цій статті ми оцінили зручність і простоту використання цієї книги. Результати дослідження представляють оцінку студентів 3 якості інтерфейсу, поданої інформації і загального задоволення від нашої електронної книги. Дослідження проводилося 3 використанням методу анкетування.
\end{abstract}

Ключові слова: EBook; EPUB3.0; зручність використання електронної книги; взаємодія алгоритмів і програмування.

\section{ОЦЕНКА УДОБСТВА ИСПОЛЬЗОВАНИЯ ЭЛЕКТРОННОЙ КНИГИ НА ОСНОВЕ ЕРUВ 3.0 ДЛЯ КУРСА ПО АЛГОРИТМАМ И ПРОГРАММИРОВАНИЮ}

\section{Гурджан Четин}

Ph.D. (Электронное и Компьютерное образование), доцент кафедры информационных систем инженерии Университет Muğla Sitkı Koçman, Мугла, Турция gcetin@mu.edu.tr

\section{Осман Озкараджа}

Ph.D. (Электронное и Компьютерное образование), доцент кафедры информационных систем инженерии Университет Muğla Sitkı Koçman, Мугла, Турция osmanozkaraca@mu.edu.tr

\author{
Мурат Сакал \\ соискатель Ph.D. (Бизнес) \\ преподаватель кафедры информатики (Центр дистанционного образования) \\ Университет Muğla Sitkı Koçman, Мугла, Турция \\ murat@mu.edu.tr
}




\section{Ерджумент Гувенч}

соискатель степени магистра (Информационные системы инженерии),

преподаватель кафедры информатики (Центр дистанционного образования)

Университет Muğla Sitkı Koçman, Мугла, Турция

eguvenc@mu.edu.tr

Аннотация. Цифровое самообучение с использованием мобильных устройств становится все более популярным среди студентов. В этом контексте, многие научные учреждения создают для своих учеников учебные цифровые ресурсы. Электронные книги (EBooks) открывают новые возможности с точки зрения визуализации учебных материалов, доступ к которым возможен с любого места в любое время. Использование интерактивных электронных книг в области инженерного образования становится неизбежным. В данной работе представлено электронную книгу для студентов, обучающихся на кафедре Информационные системы инженерии. Эта книга сфокусирована на повышении уровня алгоритмических навыков студентов. Кроме того, в этой статье мы оценили удобство и простоту использования этой книги. Результаты исследования представляют оценку студентов о качестве интерфейса, представленной информации и общего удовлетворения от нашей электронной книги. Исследование проводилось с использованием метода анкетирования.

Ключевые слова: EBook; EPUB3.0; удобство использования электронной книги; взаимодействие алгоритмов и программирования.

\section{(cc) BY-NC-SA}

This work is licensed under Creative Commons Attribution-NonCommercial-ShareAlike 4.0 International License. 